cant and unpardonable omission though is its failure to portray any evil in the immediate world comparable to what the demon perpetrates in Regan.

The Exorcist and similar contemporary cultural phenomena seem without exception to be guilty of man's recurring, intellectually primitive tendency to abdicate responsibility for his crimes by making the source of evil external to himself. For this reason alone the recurrence of the demonic persona is aesthetically unjustifiable and intellectually reprehensible. And although the literary interiorization of evil does not necessarily entail the demise of the figural, particularly in the loosing of Satan strain, the return of the demonic persona as pure externalization of evil clearly destroys any literal basis for the figural.

-JOHN R. MAY, S.J.

\title{
THE NEW RELIGIONS
}

One of my students has been interviewing recent converts to various of the "new religions" abroad in our land these days, with surprising results. Surprising to me, at least. Reading through her transcripts, I find it difficult to tell the Buddhists from the Christians. Nor can I easily discern any Buddhist content to this new Buddhism, nor Christian content to this Christianity. A student who has converted to the Nichiren Shoshu (better known in Japan as the Soka Gakkai) reports that he began chanting a little over a year ago, when his girl introduced him to the practice. Part of the appeal of Nichiren Buddhism for him was the absence of all talk of right and wrong. "I knew it didn't have a moral code," he says. "This religion doesn't treat your consciousness as being infantile."

A young woman who has found an intensely devotional relationship to Jesus through a charismatic group called the Way Ministry speaks in a very similar vein. My student asks her, "Is there a moral code in the Way Ministry that says you shouldn't do this or that?" and she responds: "No. There is an emphasis on the fact that a life that is going to be successful has to be committed to something. Christ says he came to give us a more abundant life, not a bunch of rules and regulations. In fact he came to abolish all rules and regulations, and we were set free." She goes on to say, however, that "there is definitely a way that God wants people to live; he wants you to be loving, to be good, to be good to yourself, respect yourself, and to love God more than anything else in the world. If you do that you feel really good, and your prayers are answered." 
Now some of this begins to sound like the old morality; but there is always that alien, modern element mixed in. The goal is for our lives to be successful. Prayers can be expected to bring results, and the right to happiness is close to the heart of God. The Third Person of the Blessed Trinity emerges from the mists, and bears a curious resemblance to Erich Fromm.

Our young Buddhist, having dispensed with moral matters, assures us: "The only thing you have to do to make this religion work is to chant." The chant is Nam' Myo-ho Ren-ge Kyo, Hail to the Lotus Sutra. A knowledge of that holy scripture is not required. Study is superfluous. The young man has never read it, nor sampled it. He knows how to say its name, in awkward Japanese; that is sufficient.

His girl elaborates: "I started getting into Buddhism when I was fifteen. Immediately I had this concept of Buddhism as being something very spaced out. Most people think that when you chant you're going to get high on Buddhism. That's horse----, really. I'm not concerned with the sensation I get from chanting. Everyone who begins to chant feels elated; it's a respiratory thing. But after a while-five or six years-you're not really concerned about that. I'm after fundamental things I can get from it; very substantial things."

My new-found Christian again: "You know my father is a musician, and for a long time I had a block against music. But now it's cool. I'm picking up the guitar again, and playing clarinet again, and now I can do it. Fear always stops a person from fulfilling his potential." My student asks if she has new confidence now that she feels that God is with her. "Right. Well, even if God is with me, I know it's contingent on $m y$ believing. I know if I set my head, and say I can learn how to play the clarinet, I can do it in two months. I really get to believing, and I can do it." My student asks what all this has to do with the Bible. "It's a spiritual law God set up from the beginning. Rockefeller uses the law of believing for his stocks. He wouldn't put money into a stock unless he believed that stock would increase his wealth." My student nobly asks again what this has to do with the Bible. "Okay. So if you know that law that everything you believe in you are going to receive, I think that's mainly what I have gained, is that help. It's a law like gravity." My student makes one last stab: Is this "law" in some sense a spiritual law? "Well, the reason it works is because it's a spiritual law. A lot of religions have truth in them, or else nobody would use them."

And there is the message of all this. Religions, all religions, have utility. Because they are useful, they should be used, have been used, are used. Buddhism works. Christianity works. Prayer works. Chanting works. The content of the chant matters nought. You may substi- 
tute La ilaha illa'llah if you prefer, or Hare Krishna Hare Krishna, or Pandurang Pandurang. The power is not in the meaning of the words, but in their sounds, and in the doing of the sounds, it is not, as Deweyites once assured us, that we learn by doing; it is rather that we get by doing. Religion has to do with getting, not with being or becoming, thinking or feeling. If it works, use it.

But this is not good Buddhism, nor good Christianity, nor for that matter good Hinduism. Probably the mischief started when Westerners began to read the classics of Indian mysticism. The goal, they saw, was somehow to reach the Self, the true Self, the core, the essence of our being. The error is in confusing self with Self. This Self which is the quintessence of all we are and can be is somehow beyond the self. What is worse, it is our very self that obstructs, that blocks the path to this Selfhood, this completion we seek. "I have wandered through many lives seeking the builder of this house and finding him not," says the Buddha. The "house" is the network of selfishness and self-centeredness that entraps him. And the builder of the house is of course none other than his own self. How does self accuse self of playing self false? That is the riddle of enlightenment for the Buddhists. So long as it remains unsolved, there can be no genuine salvation. Yet it is not so much a problem to be solved; it is more a barrier to be leaped, a limitation to be outgrown. The religious life, Christian or Buddhist, calls for a very special kind of spiritual growth and transformation, which is effected, not by following the desires of the self, but by re-centering one's selfhood somehow outside the limits of self.

To the new believers in the new religions, I would offer this fragment of a poem by Edward Thomas:

... If I could choose

Freely in that great treasure-house

Anything from any shelf, I would give you back yourself, And power to discriminate

What you want and want it not too late, Many fair days free from care

And heart to enjoy both foul and fair, And myself, too, if I could find

Where it lay hidden and it proved kind.

-ALBERT WILLIAM SADLER 